\title{
Left-sided approach of AV junction ablation for drug refractory atrial fibrillation
}

\author{
Yoga Yuniadi, Retna Dewayani, M Munawar, Otte J Rachman
}

\begin{abstract}
Abstrak
Ablasi AV junction terbukti efektif pada pasien atrial fibrilasi $(A F)$ yang refrakter dengan isolasi vena pulmonalis maupun antiaritmia. Akan tetapi pada hampir 15\% kasus ablasi AV junction dengan teknik konvensional (sisi-kanan) gagal. Penelitian ini bertujuan mempelajari karakteristik potensial berkas His pada ablasi AV junction secara konvensional maupun dengan teknik sisi-kiri. Dua puluh pasien AF yang simtomatik dan refrakter terhadap antiarimia (rerata umur 60,5 $\pm 9,28$ tahun, 11 wanita) dilakukan ablasi AV junction dengan teknik konvensional. Bila 10 kali aplikasi energi frekuensi-radio tidak dapat menyebabkan blok AV total, maka ablasi dilakukan melalui sisi-kiri. Amplitud berkas His yang terekam pada tempat ablasi dianalisa. Seluruh pasien berhasil diablasi, 17 dengan cara konvensional dan 3 pasien degan teknik sisi-kiri setelah teknik konvensional gagal. Amplitud berkas His pada sisi-kiri lebih besar daripada sisi-kanan yang berkesesuaian (16,0 \pm 4,99 mm vs. 6,9 \pm 4,02 mm, p = 0,001, 95\% IK -14,0 to -4,3). Dengan nilai titik potong amplitude berkas His sisi-kanan > 4,87 mm didapatkan sensitifitas $81.3 \%$ dan spesifisitas 53,8\% untuk keberhasilan ablasi pada sisi yang bersangkutan. Teknik sisi-kiri pada ablasi AV junction efektif bila teknik konvensional gagal. Pada pasien dengan amplitud berkas His sisi-kanan yang rendah $(<4,87 \mathrm{~mm})$ dianjurkan untuk ablasi dengan teknik sisi-kiri untuk menghindari pemberian energi frekuensi-radio yang tidak perlu. (Med J Indones 2006; 15:109-14)
\end{abstract}

\begin{abstract}
$A V$ junction ablation has been proven effective to treat symptomatic atrial fibrillation refractory to antiarrhythmias or fail of pulmonary vein isolation. However, about $15 \%$ of conventional right-sided approach AV junction ablation failed to produce complete heart block. This study aimed to characterize His bundle potential at ablation site during conventional or left-sided approach of AV junction ablation. Twenty symptomatic AF patient (age of $60.5 \pm 9.28$ and 11 are females) underwent conventional AV junction ablation. If 10 applications of radiofrequency energy are failed, then the ablation was performed by left-sided approach. Seventeen patients are successfully ablated by conventional approach. In 3 patients, conventional was failed but successfully ablated by leftsided approach. The His bundle amplitude at ablation site was significantly larger in left-sided than correspondence right-sided (16.0 $\pm 4.99 \mathrm{~mm}$ vs. $6.9 \pm 4.02 \mathrm{~mm}$ respectively, $p=0.001,95 \%$ CI -14.0 to -4.3$)$. ROC analysis of His bundle potential amplitude recorded from right-sided revealed that cut off point of $>4.87 \mathrm{~mm}$ given the sensitivity of $81.3 \%$ and specificity of $53.8 \%$ for successful rightsided approach of AV junction ablation. In case of failed conventional approach, the left-sided approach is effective for AV junction ablation. An early switch to the left-sided approach may avoid multiple RF applications in patients with a low amplitude His-bundle potential $(<4.87 \mathrm{~mm}$ ). (Med J Indones 2006; 15:109-14)
\end{abstract}

Keywords: Atrial fibrillation, AV junction ablation, left-sided approach

Atrioventricular (AV) junction ablation and pacemaker implantation has been effectively proven to manage symptomatic drug refractory chronic atrial fibrillation (AF). ${ }^{1}$ Recently the knowledge of AF has been markedly improved and the magnitude of $\mathrm{AF}$ ablation technique has been changed to the pulmonary

Department of Cardiology and Vascular Medicine, Faculty of Medicine, University of Indonesia, and National Cardiovascular Center Harapan Kita, Jakarta, Indonesia vein isolation (PVI). However, more than $30 \%$ of $\mathrm{AF}$ cases were left untreated and/or recurred after PVI. Thus, AV junction ablation still has a place as an AF management procedure especially in drug refractory symptomatic cases. In addition, AV junction ablation has been effectively proven to improve quality of life and exercise performance. Since AV node is laid at right side of the AV septum, right-sided approach of AV junction ablation is thought to give highly success rate. However, in 10-15\% of patients right-sided approach is either unsuccessful and/or very difficult. ${ }^{2,3}$ 
We studied the electrophysiology characteristics of AF patients who undergone successful AV junction ablation using left-sided approach after failed of rightsided approach. Left-sided approach in case of failed right-sided approach of $\mathrm{AV}$ junction ablation has not been widely elucidated. The aim of this study was to find the electrophysiologic parameters to determine the timing of changing from right-sided to left-sided approach of AV junction ablation to get immediate success without unnecessary and risky right heart chambers ablation.

Table 1. Clinical characteristics

\begin{tabular}{|c|c|c|}
\hline \multicolumn{3}{|c|}{ PARAMETERS } \\
\hline \multicolumn{3}{|l|}{ Sex } \\
\hline$>$ & Male & $9(45 \%)$ \\
\hline$>$ & Female & $11(55 \%)$ \\
\hline \multirow{3}{*}{ Age } & & $60.5 \pm 9.28$ yo \\
\hline & Male & $56.6 \pm 8.59$ yo \\
\hline & Female & $63.8 \pm 8.86$ yo \\
\hline \multicolumn{3}{|c|}{ Underlying disease } \\
\hline$>$ & $\mathrm{CAD}$ & 9 \\
\hline$>$ & Hypertension & 6 \\
\hline$>$ & Valvular heart disease & 3 \\
\hline$>$ & Others structural heart disease & 7 \\
\hline \multicolumn{3}{|c|}{ AV junction ablation approach } \\
\hline$>$ & Right-sided & $17(85 \%)$ \\
\hline$>$ & Left-sided & $3(15 \%)$ \\
\hline \multicolumn{3}{|c|}{ Implanted Permanent pace maker } \\
\hline$>$ & VVIR & $17(85 \%)$ \\
\hline$>$ & CRT & $3(15 \%)$ \\
\hline
\end{tabular}

Clinical characteristics of study subject are presented as proportion and absolute number. $\mathrm{CAD}=$ coronary artery disease, VVIR = pacemaker mode with ventricular pacing and sensing site accompanied with rate response mode.

\section{METHODS}

\section{Patients}

From October 2004 up to January 2006, 20 consecutive symptomatic drug refractory AF patients (age of 60.5 \pm 9.28 and 11 are females) underwent AV junction ablation. Of 20 patients, 9 had coronary artery disease, 6 had hypertension, 3 had valvular disease, and 7 had other structural heart disease.

\section{Electrophysiology study}

After written informed consent was obtained the patient underwent electrophysiology study (EPS) and radiofrequency (RF) ablation procedure. The protocol of EPS and RF ablation of AV junction has been published elsewhere. ${ }^{4}$ In brief, the procedure started by local anesthesia of right inguinal area followed by insertion of one $6 \mathrm{~F}$ quadripolar electrode catheter into the right ventricle apex and one 7F $4 \mathrm{~mm}$ ablation catheter was placed at His bundle area in superior region of tricuspid annulus. (Figure 1) We tried to get the biggest His bundle potential characterized with $\mathrm{A}$ wave to $\mathrm{V}$ wave amplitude ratio about 1:3. The Prucka Cardiolab system (Massachuset, USA) was used to perform electrophysiology study and recording. After having sufficient $\mathrm{A}$, His and $\mathrm{V}$ potentials recording, the radiofrequency energy from RF machine (Stockert, Biosense Webster, USA) with power of 40 watt, temperature of $60^{\circ} \mathrm{C}$ was delivered lasting for 60 second. If $10 \mathrm{RF}$ deliveries were not success then we changed to left-sided approach by retrograde technique. For that purpose, additional puncture of right femoral artery was performed. As the ablation catheter enter the left ventricle out flow tract, we mapped the His bundle potential. RF energy was delivered at the site below aortic valves given the biggest $\mathrm{His}$ bundle potential. (Figure $\mathbf{2 A}$ and B) The successful RF ablation was defined if complete heart block with idioventricular or junctional escape rhythm was occurred. (Figure 3) A temporary pacemaker was inserted until the permanent one implanted.

\section{His bundle potential measurement}

The His bundle potential amplitude was measured from printed paper of intracardiac electrograms recorded by ablation catheter at ablation site. Magnification scale of intracardiac tracing was $1 / 8$. Two independent observers measured 5 largest His potentials in a consecutive manner using digital caliper (Absolute Digimatic, Mitutoyo, Japan) at paper speed of $100 \mathrm{~mm} / \mathrm{sec}$. Measurement was conducted twice with more than 24 hours interval.

\section{Statistical Analysis}

Continues data were presented as mean \pm SD. Comparisons of the His bundle amplitude from rightsided and left-sided recording were performed using two-tailed student-t test. The cut off point of rightsided His bundle amplitude for successful ablation was determined by ROC analysis. The intra and interobserver variations of measurement were determined. A $p$ value of $<0.05$ was considered statistically significant. 


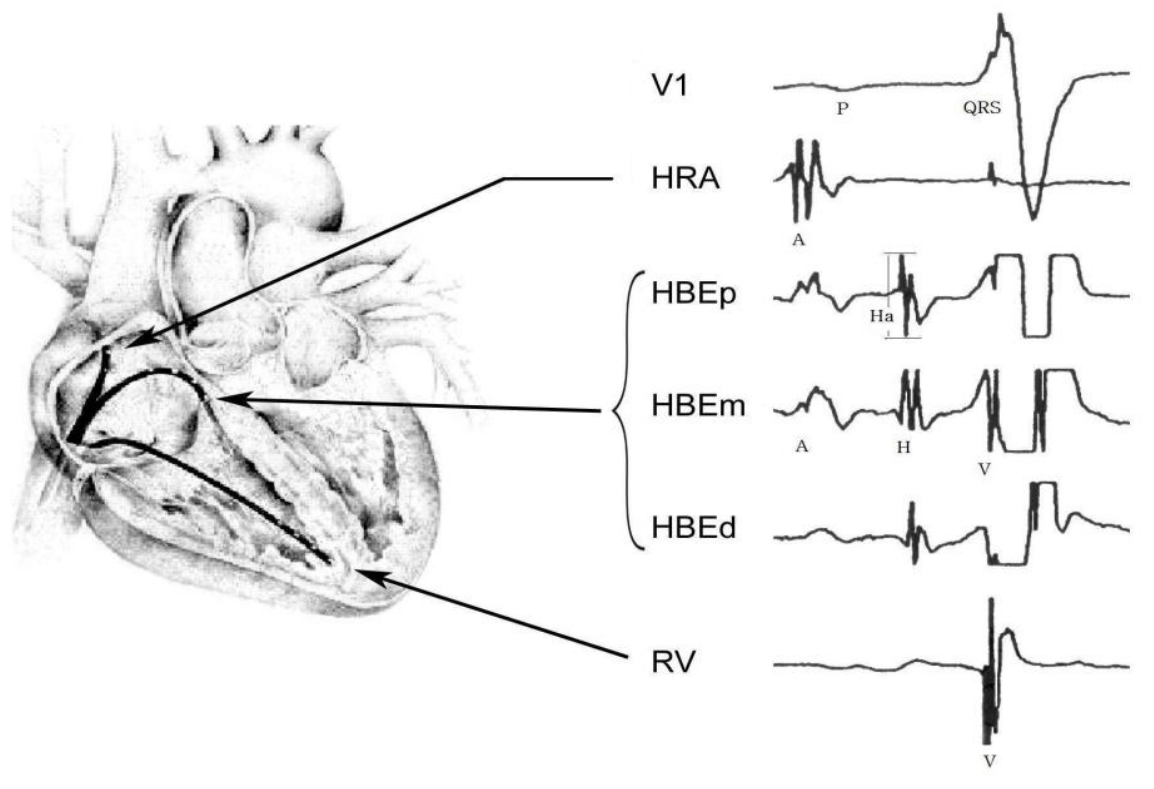

Figure 1. Catheters placement and intracardiac recordings

The left panel demonstrates a diagram of electrodes placement in the heart chambers. Three quadripolar electrode catheters inserted into the heart and placed at high lateral wall of right atrium (HRA), superior to annulus tricuspid (HBE), and apex of right ventricle $(R V)$. The right panel demonstrates ECG recording of VI lead and intracardiac recording revealed from each electrode catheter. The HRA electrode demonstrates atrial potential (A) and farfield V potential. The HBE electrode demonstrates atrial potential (A), His bundle potential $(H)$ and $V$ potential. The $R V$ lead demonstrates $V$ potential. The amplitude of His bundle potential was measured along its height $(\mathrm{Ha}) . H R A=$ high right atrium, $H B E=$ His bundle electrogram $(p=$ proximal, $m=$ mid, $d=$ distal), $R V=$ right ventricle .
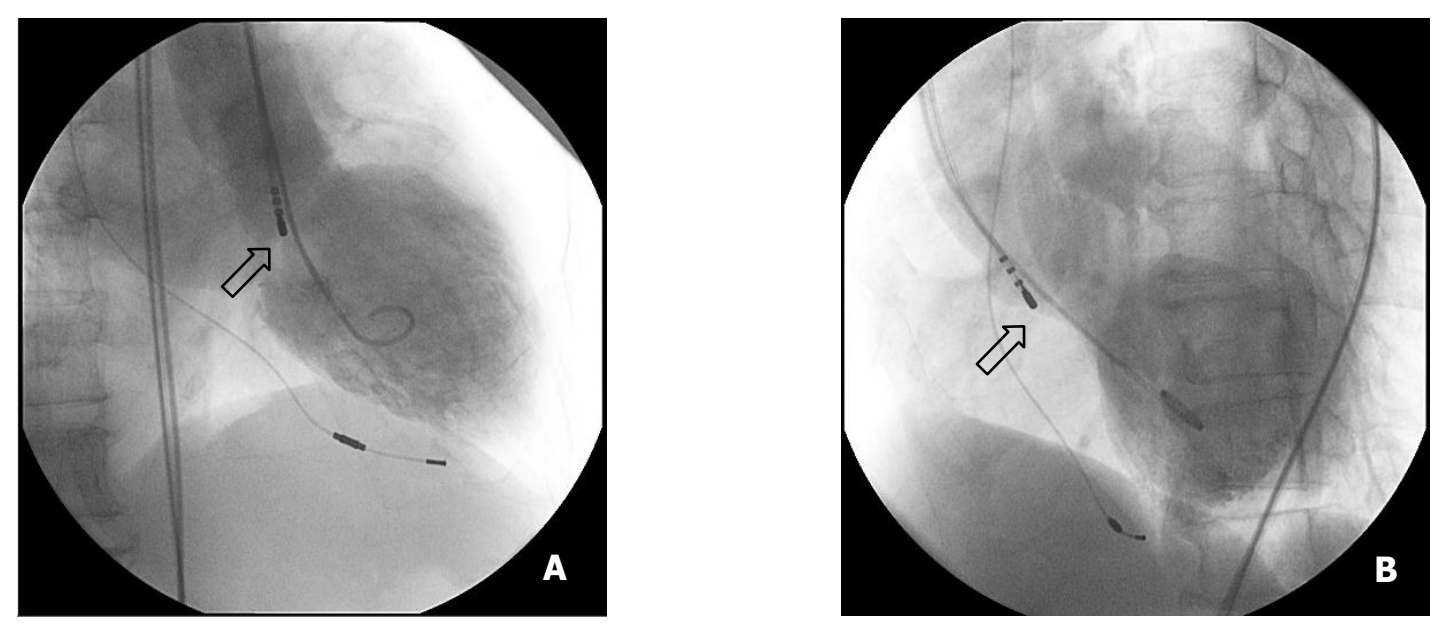

Figure 2. Fluoroscopic Images of left-sided ablation site.

The figures shows ablation catheter position during left-sided approach of AV junction ablation. Panel A shows the position of ablation catheter as seen in 30 degree right anterior oblique view (RAO-30) and the panel B is seen from 60 degree left anterior oblique view (LAO-60). The tip of ablation catheter (blank arrow) was directed to the septal aspect of left ventricle outflow tract just below the aortic valve. 


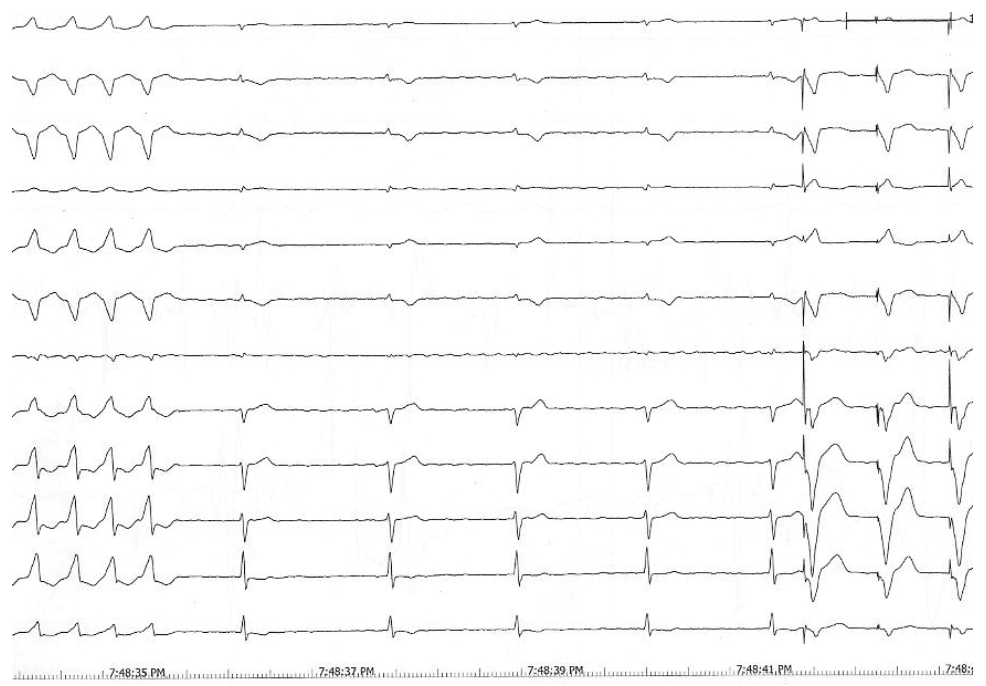

Figure 3. ECG pattern changes during RF ablation.

The figure shows changes of 12-lead ECG pattern from atrial fibrillation with rapid ventricular response on the left side to be the slow junctional rhythm in the center and finally right ventricle pacing rhythm at $1000 \mathrm{~ms}$ cycle length.

\section{RESULTS}

\section{His bundle potential}

The overall mean of right-sided His bundle potential amplitude was $7.7 \pm 4.51 \mathrm{~mm}$. The mean amplitude of those successfully ablated by right-sided approach was $7.9 \pm 4.60 \mathrm{~mm}$. Three patients who were failed of right-sided ablation but successfully ablated by leftsided approach demonstrated smaller right-sided His bundle potential amplitude $(6.9 \pm 4.02 \mathrm{~mm})$, but did not reach statistical significance compare to that of successful right-sided ablation group $(\mathrm{p}=0.44)$. ROC analysis of His bundle potential amplitude recorded from right-sided revealed the area under curve of 0.60 . The His bundle amplitude cut off point of $>4.87 \mathrm{~mm}$ given the sensitivity of $81.3 \%$ and specificity of $53.8 \%$ for successful right-sided approach of AV junction ablation (Figure 4).

Among patient who underwent left-sided approach AV junction ablation after failed right-sided approach, the His bundle amplitude recorded at ablation site was significantly larger than correspondence right-sided amplitude $(16.0 \pm 4.99 \mathrm{~mm}$ vs. $6.9 \pm 4.02 \mathrm{~mm}$ respectively, $\mathrm{p}=0.001,95 \% \mathrm{CI}-14.0$ to -4.3$)$. Meanwhile, the amplitude of His bundle potential recorded at all successful ablation site, revealed significantly smaller right-sided amplitude compare to that of leftsided amplitude.

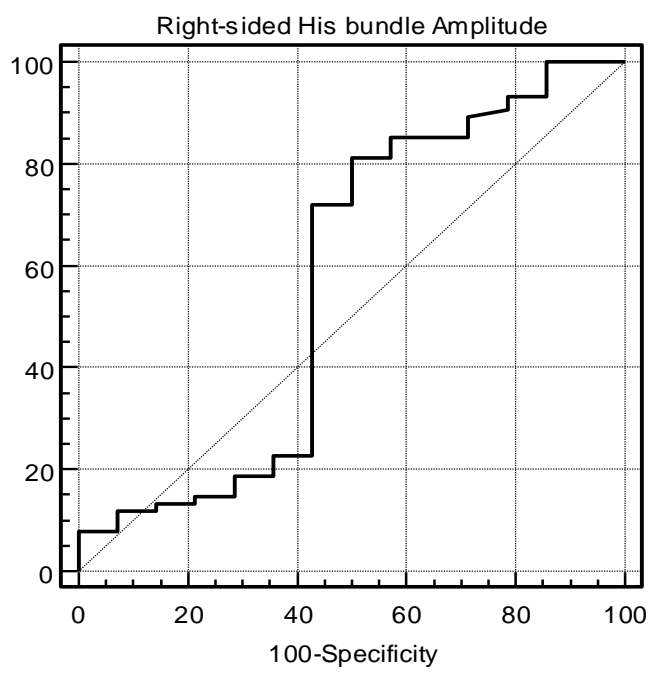

Figure 4. ROC Analysis of right-sided His bundle amplitude. This figure is a receiver operating curve (ROC) analysis of right-sided His bundle amplitude. A cut off point of $>4,87 \mathrm{~mm}$ given the sensitivity of $81.3 \%$ and specificity of $53.8 \%$ for successful right-sided approach of $A V$ junction ablation.

Intra-observer measurements variation demonstrated Pearson correlation coefficient of 0.998 and 0.996 for observer 1 and observer 2 , respectively $(\mathrm{p}<0.001$ ). Inter-observer measurement variation was significantly correlated $(\mathrm{p}<0.001)$ with Pearson coefficient correlation of 0.994 . 


\section{RF ablation outcome}

All patients were successfully ablated. The number of RF application was higher with right-sided approach compare to that of left-sided approach but did not reach statistical significance $(5.6 \pm 8.5$ vs $2.3 \pm 1.53$, p= 0.172 , respectively). All but 3 patients demonstrated junctional rhythm during RF ablation just before the occurrence of AV block. Of 20, 6 (30\%) patients showed junctional and $14(70 \%)$ showed idioventricular escape rhythm after successful AV junction ablation. Three patients were received cardiac resynchronization device therapy after AV junction ablation, and the rest were implanted ventricular pacemaker with rate responsive mode.

\section{DISCUSSION}

This study demonstrated that ablation of AV junction using the left-sided approach successfully produced complete heart block when preceding frequent rightsided radiofrequency applications were failed. In those cases, the left-sided His bundle amplitude was significantly greater than that of corresponding rightsided amplitude. The cut off point of $>4.87 \mathrm{~mm}$ for His amplitude given a sensitivity of $81.3 \%$ and specificity of $53.8 \%$ for successful right-sided approach of AV junction ablation. This finding confirms what was previously reported by Abe et $\mathrm{al}^{4}{ }^{4}$ They used electronic caliper of Prucka system to measure His potential amplitude and found that the probability of successful ablation with a conventional right-sided approach was 6 out of 12 patients (50\%) if the His amplitude was $<0.12 \mathrm{mV}$, and 17 out of 18 patients $(94 \%)$ if the His amplitude was $>0.12 \mathrm{mV}(\mathrm{p}<0.005)$. The His amplitude recorded from the left side using the same catheter was significantly greater than that on the corresponding right-side $(0.22 \pm 0.09 \mathrm{mV}$ vs $0.12 \pm 0.04 \mathrm{mV}$, respectively with $\mathrm{p}<0.05$ ).

The excellent correlations in intra- and inter-observer measurements favor the objectivity of all measurements process and tools. The digital caliper measurement apply to the magnified his bundle potential could be used as an alternative to usual electronic caliper measurement owned by the electrophysiology machine.

In our study successful AV junction ablation achieved with fewer left-sided RF applications compare to that of right-sided applications, but it was not reach statistical significance. Of 3 patients who failed rightsided approach ablation required a median of 18 failed
RF applications (8-28 applications), but only required a median of 2 subsequent RF applications for success on the left side (1-4 applications). This is consistent with previous report by Abe et $\mathrm{al}^{4}$ who required fewer application from left-sided approach after multiple failed right-sided RF applications.

The majority of patients demonstrated junctional rhythm just before the occurrence of complete heart block during RF ablation. The presence of junctional rhythm during slow pathway ablation of AVNRT has long been known as a predictor of complete heart block. Junctional rhythm is believed resulted from injury of AV nodal body by heating from ablation catheter. As heating continued, the nodal body was destroyed resulted in complete heart block. In 70\% of patients of our study, the RF ablation completely damaged the nodal body causing an idioventricular escape rhythm, however, the rest showed slow junctional escape rhythm. Similar findings have been reported by other authors. Curtis et $\mathrm{al}^{5}$ reviewed the escape rhythm of patients underwent successful AV junction ablation in the Ablate and Pace trial. They found that escape rhythm was present in 104 patients (67\%) after RF ablation. The escape rate ranged from 11 to 65 beats/min (mean $39 \pm 10$ beats/min). Only 49 patients $(31 \%)$ had an escape rate $\geq 40$ beats $/ \mathrm{min}$. Of the 104 patients with an escape rhythm, 53 patients (51\%) had a QRS that was unchanged from baseline. There was no correlation between the number of radiofrequency applications and the presence of an escape rhythm. Shepard et $\mathrm{al}^{6}$ reported that isoproterenol and atropine increased the escape rate, slowed with lidocaine but it was unaffected by adenosine and verapamil administration. The authors concluded that escape rhythm can be responsive to sympathetic stimulation and vagal blockade.

The benefits of AV junction ablation have been proven by several studies. For the majority of patients undergoing AV junction ablation, drug therapy can be stopped, thus eliminating adverse effects of drug therapy including negative inotropic effects, proarrhythmic risks, and chronic medication cost. Of 156 symptomatic AF patients in the Ablate and Pace Trial, who underwent AV junction ablation and pacing demonstrated improvement of arrhythmias-related symptoms, quality of life scores, and New York Heart Association (NYHA) functional class after 3 and 12 months follow-up.

The choice of permanent pacemaker after the AV junction ablation has not been widely elucidated. In 
our case, all but 3 have been implanted single chamber pacemaker with rate responsive mode. Carmouche et al, reported the use of single chamber pacemaker with optimal rate responsive mode and upper limit programming can improve exercise performance and exertional symptoms. ${ }^{8}$ Three patients underwent cardiac resynchronization therapy (CRT) after AV junction ablation, due to the evidence of intra- and inter-ventricular dyssynchrony. Recently, the CRT is started to be used in AF patient with refractory heart failure undergoing AV junction ablation. Kies et $\mathrm{al}^{9}$, studied 74 consecutive patients with advanced HF and AF (20 persistent; 54 permanent) who were implanted with a CRT. The study aimed to evaluate clinical (NYHA class, quality of life, 6 minute walk test) and echocardiographic (LV ejection fraction, LV diameters and left atrial diameters) measures before and after 6 months of CRT. At the end of the study, they concluded that 6 months of CRT resulted in significant clinical benefit with significant left atrial and LV reverse remodeling. Despite these beneficial effects, reversal to SR was not established in $93 \%$ of patients.

\section{Limitation}

In this study, the left-sided approach technique was performed as an alternative to the failed right-sided approach. Since only a thin membranous septal that separate left ventricle outflow tract with the location of $\mathrm{AV}$ junction, any influence of preceding frequent right-sided approach to the success left-sided approach should be considered. The randomized longitudinal study should be addressed to answer which one is the better technique between right and left-sided approach for $\mathrm{AV}$ junction ablation.

\section{CONCLUSION}

The His bundle amplitude of $>4.87 \mathrm{~mm}$ given a sensitivity of $81.3 \%$ and specificity of $53.8 \%$ for successful AV junction ablation using right-sided approach. In case of failed right-sided approach, the left-sided approach is effective with fewer RF applications. The amplitude of His bundle potential recorded at ablation site was higher at left-sided compare to that of right-sided. An early switch to the left-sided approach may avoid multiple RF applications in patients with a low amplitude His-bundle potential.

\section{REFERENCES}

1. Brignole M, Gianfranchi L, Menozzi C, Alboni P, Musso $\mathrm{G}$, Bongiorni MG, et al. Assessment of atrioventricular junction ablation and DDDR mode-switching pacemaker versus pharmacological treatment in patients with severely symptomatic paroxysmal atrial fibrillation: a randomized controlled study. Circulation 1997; 96(8): 2617 - 24

2. Evans GT, Jr., Sceinman MM, Zipes DP, Benditt D, Breithardt G, Camm AJ, et al. The percutaneous cardiac mapping and ablation registry: summary of results. Pacing Clin Electrophysiol. 1987; 10(6): 1395 - 9

3. Huang SK, Bharati S, Graham AR, Lev M, Marcus Fl, Odell RC. Closed chest catheter desiccation of the atrioventricular junction using radiofrequency energy - a new method of catheter ablation. J Am Coll Cardiol. 1987; 9(2): $349-58$

4. Abe H, Bhandari AK, Lerman R, Isber N, Abdullah E, Firth B, et al. A low amplitude His-bundle potential predicts failure of the right-sided approach for atrioventricular junction ablation. Jpn Circ J. 2000; 64(4): $257-61$

5. Curtis AB, Kutalek SP, Prior M, Newhouse TT. Prevalence and characteristics of escape rhythms after radiofrequency ablation of the atrioventricular junction: results from the registry for $\mathrm{AV}$ junction ablation and pacing in atrial fibrillation. Ablate and Pace Trial Investigators. Am Heart J. 2000; 139 (1 Pt 1): 122 - 5

6. Shepard RK, Natale A, Stambler BS, Wood MA, Gilligan DM, Elenbogen KA. Physiology of the escape rhythm after radiofrequency atrioventricular junctional ablation. Pacing Clin Electrophysiol. 1998: 21(5): 1085 - 92

7. Kay GN, Ellenbogen KA, Giudicci M, et al. The Ablate and Pace Trial: a prospective study of catheter ablation of the AV conduction system and permanent pacemaker implantation for treatment of atrial fibrillation. APT Investigators. J Intervent Cardiac Electrophysiol. 1998; 2(2): $121-135$

8. Carmouche DG, Bubien RS, Kay GN. The effect of maximum heart rate on oxygen kinetics and exercise performance at low and high workloads. Pacing Clin Electrophysiol. 1998; 21 (Pt.I): 679 - 86

9. Kies P, Leclercq C, Bleeker GB, Crocq C, Molhoek SG, Poulain $\mathrm{C}$, et al. Cardiac resynchronization therapy in chronic atrial fibrillation: impact on left atrial size and reversal to sinus rhythm. Heart. 2005; 91(9): epub. 